\title{
Behavior of Araujiain, a new cysteine phytoprotease, in organic media with low water content
}

\author{
Evelina Quiroga \\ Laboratorio de Bromatología \\ Facultad de Química, Bioquímica y Farmacia \\ Universidad Nacional de San Luis \\ Chacabuco y Pedernera 5700, San Luis, Argentina \\ Tel: 542652423789 ext. 155 \\ Fax: 542652431301 \\ E-mail:equiroga@unsl.edu.ar \\ Nora Priolo \\ Laboratorio de Investigación de Proteínas Vegetales (LIPROVE) \\ Facultad de Ciencias Exactas \\ Universidad Nacional de La Plata \\ 47 y 115 (1900), La Plata. Argentina \\ Tel: 00542214230121 ext.157 \\ Fax: 00542214224064 \\ E-mail: priolo@nahuel.biol.unlp.edu.ar \\ José Marchese \\ Laboratorio de Ciencias de Superficies y Medios Porosos \\ Universidad Nacional de San Luis \\ Chacabuco y Pedernera 5700, San Luis, Argentina \\ Tel: 00542652423789 ext. 116 \\ Fax: 00542652430224 \\ E-mail:marchese@unsl.edu.ar \\ Sonia Barberis* \\ Laboratorio de Bromatología \\ Facultad de Química, Bioquímica y Farmacia \\ Universidad Nacional de San Luis \\ Chacabuco y Pedernera 5700, San Luis, Argentina \\ Tel: 542652423789 ext. 155 \\ Fax: 542652431301 \\ E-mail: sbarberi@unsl.edu.ar
}

Financial support: The present work was supported by grants from CIC, ANPCyT, Universidad Nacional de San Luis and Universidad Nacional de La Plata, Argentina.

Keywords: Araujia hortorum Fourn., organic solvents, plant protease, substrate preferences, thermostability.

In this paper we studied the effect of different organic solvents (1-octanol, trichloroethylene, ethanol, ethyl acetate, tetrahydrofuran, cyclohexane, propanone, acetonitrile, dichloromethane, chlorobenzene, N,Ndimethylformamide, acetophenone, diethyl ether, methanol, ethylene glycol and toluene) with low and constant water content on substrate preferences, thermostability and stability (caseinolytic activity retention after $4 \mathrm{~h}$ ) of proteases of Araujia hortorum Fourn. (Asclepiadaceae). The stability of araujiain was high in $\mathrm{N}, \mathrm{N}$-dimethylformamide and ethanol at $40^{\circ} \mathrm{C}$, but decreased at higher temperature. Araujiain substrates preferences in buffer Tris-HCl (pH 8), ethylene glycol and $\mathrm{N}, \mathrm{N}$-dimethylformamide exhibited different patterns, but the enzyme showed a high preference by glutamine derivative in all cases. According to FTIR spectroscopy studies, araujiain changed its secondary structure and as a consequence, it also changed its substrate preferences. This enzyme showed lower $\alpha$-helical character and greater $\beta$-sheet folding in buffer than in organic media. A larger amount of antiparallel $\beta$-sheet residues indicates the formation of tighter intermolecular hydrogen bonds and enzymatic aggregates. These facts could explain the higher esterolytic activities, the greater stability and good hydrolytic potential of araujiain in some organic media such as $\mathbf{N}, \mathbf{N}$-dimethylformamide.

The suspension or dissolution of enzymes into non-aqueous

* Corresponding author 
solvents offers many advantages over the use of enzymes in aqueous solutions, such as the use of substrates with low solubility in water, the change of the thermodynamic balance in favour of the synthesis, the reduction of the inhibition due to substrates and/or products, the easy recovery of product and biocatalyst, the increase of the thermostability and the change of the substrate specificity of some enzymes (Illanes and Barberis, 1994; Wescott and Klibanov, 1994; Carrea et al. 1995; Yennawar et al. 1995; $\mathrm{Xu}$ and Klibanov, 1996; Kawashiro et al. 1997; Lortie, 1997; Ke and Klibanov, 1998; Colombo et al. 2000; Klibanov, 2001). These facts have extended the use of enzymes as highly specific catalysts for resolution of racemic mixtures, oxidation of steroids and synthesis of esters and peptides, among other applications.

Unfortunately, there are also some drawbacks, such as the limited application of enzymes due to their high specificity and selectivity, formation of secondary product, secondary hydrolysis of the product and substrates, changes in the enzyme activity and stability (Carrea and Riva, 2000). However, the use of different strategies such as the enzyme immobilization, and media and enzyme engineering are progressively reducing these limitations.

According to some authors, the water content in organic media determines the changes that the biocatalyst suffers in that media (Zaks and Klibanov, 1988; Halling 1989). Thus, in order to study the effect of organic solvents on the behavior of an enzyme, it is necessary to fix constant water content on the enzyme.

In this paper we studied the effect of different organic solvents (1-octanol, trichloroethylene, ethanol, ethyl acetate, tetrahydrofuran, cyclohexane, propanone, acetonitrile, dichloromethane, chlorobenzene, N,Ndimethylformamide, acetophenone, diethyl ether, methanol, ethylene glycol and toluene) with low and constant water content on substrate preferences, thermostability and stability (caseinolytic activity retention after $4 \mathrm{~h}$ ) of proteases of Araujia hortorum Fourn. (Asclepiadaceae).

\section{MATERIALS AND METHODS}

\section{Materials}

Araujiain is the crude enzyme preparation obtained from the latex of fruits of Araujia hortorum Fourn. (Asclepiadaceae). This preparation contains cysteine proteases belonging to the papain family (Priolo et al. 2000; Obregon et al. 2001).

\section{Caseinolytic activity measurement}

Proteolytic assays were performed using casein (Hammarsten type, Research Organics, Cleveland, OH, USA) as substrate. The reaction mixture was prepared by mixing $0.1 \mathrm{ml}$ of the enzyme with $1.1 \mathrm{ml}$ of $1 \%$ casein containing $12 \mathrm{mM}$ Cys, in $0.1 \mathrm{M}$ Tris- $\mathrm{HCl}$ buffer (pH 8). The reaction was carried out at $40^{\circ} \mathrm{C}$, and it was stopped 10 min later by the addition of $1.8 \mathrm{ml}$ of $5 \%$ trichloroacetic acid (TCA). Each test tube was centrifuged at 3,000 $\mathrm{x}$ g for $30 \mathrm{~min}$, and the absorbance of the supernatant was measured at $280 \mathrm{~nm}$. An arbitrary enzyme unit (caseinolytic unit, Ucas) was defined as the amount of protease, which produces an increment of one absorbance unit per min in

Table 1. Amount of water (\% (v/v)) added to the organic solvents necessary to obtain a constant relative fraction of water in the enzyme, independently of the hydrophobicity of the used solvent.

\begin{tabular}{|c|c|c|c|}
\hline Organic solvent & $\begin{array}{c}\%(\mathbf{v} / \mathbf{v}) \text { of water added to the } \\
\text { organic solvent }\end{array}$ & $\begin{array}{c}\%(\mathbf{w} / \mathbf{w}) \text { of water in the } \\
\text { enzyme }\end{array}$ & $\begin{array}{c}\text { Relative fraction of water in the } \\
\text { enzyme }\end{array}$ \\
\hline Acetonitrile & 5.6 & 50 & 0.5 \\
\hline Acetophenone & 2.13 & 49.8 & 0.5 \\
\hline Chlorobenzene & 2.5 & 50.26 & 0.5 \\
\hline Ciclohexane & 0.89 & 50.08 & 0.5 \\
\hline Diethvl ether & 1.02 & 50.22 & 0.5 \\
\hline Dichloromethane & 3.4 & 50 & 0.5 \\
\hline Ethanol & 9.43 & 50 & 0.5 \\
\hline Ethvl acetate & 2.5 & 50 & 0.5 \\
\hline Ethvlene alvcol & 17.8 & 50 & 0.5 \\
\hline Methanol & 13 & 50 & 0.5 \\
\hline N.N-dimethvlformamide & 18.57 & 50 & 0.5 \\
\hline 1-Octanol & 0.63 & 50 & 0.5 \\
\hline Propanone & 7.25 & 50 & 0.5 \\
\hline Tetrahvdrofuran & 5 & 50 & 0.5 \\
\hline Toluene & 0.88 & 50.28 & 0.5 \\
\hline Trichloroethvlene & 2 & 50.4 & \\
\hline
\end{tabular}


the assay conditions (Priolo et al. 2000).

\section{Selection of organic solvents}

A statistical design was carried out by clustering 70 organic solvents according to their physico-chemical properties (descriptors) extracted from the literature (Abraham and Gowan, 1987; Abraham and Grellier, 1988; Abraham et al. 1991; Reichardt, 1994; Abboud and Notario, 1999), and one representative organic solvent of each group was chosen for the study.

\section{Determination of water content}

The amount of water on the enzyme after incubation in organic media with different concentration of water was determined as follows: $10 \mathrm{mg}$ of enzyme and $10 \mathrm{ml}$ of a solvent containing a given amount of water were placed in a preweighted centrifuge tube and incubated for $10 \mathrm{~min}$ at $25^{\circ} \mathrm{C}$. The suspension was then centrifuged for $5 \mathrm{~min}$, and the liquid was separated from the solid phase by decantation. The amount of water in the liquid phase and in the pellet was measured by the optimized Karl Fisher method (Laitinen and Harris, 1982) using a coulometric KF tritator (model 270, Denver Instrument). The amount of water in the pellet corresponds to the sum of water in the enzyme and the amount of water in the entrapped organic solvent in the enzyme. Then, the net amount of water in the enzyme was determined by subtracting the amount of water in the entrapped organic solvent to the amount of water in the pellet. The last one was calculated on the basis of the weight of the entrapped organic solvent (difference between the weight of the tube with the pellet and the weight of the tube with the dry enzyme) and the amount of water in the solvent (supernatant) (Zaks and Klibanov, 1988). The water contents in organic solvents and in the enzyme were determined as volume to volume $(\mathrm{v} / \mathrm{v})$ percent and weight to weight $(\mathrm{w} / \mathrm{w})$ percent, respectively.

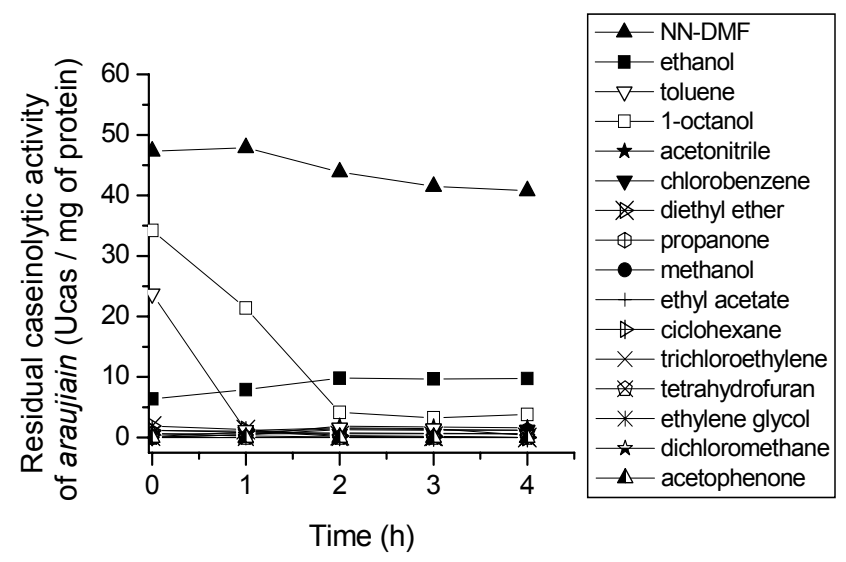

Figure 1. Residual caseinolytic activity of araujiain (Ucas/mg of protein) in different organic solvents with low water content, $\mathrm{pH} 8$ and $40^{\circ} \mathrm{C}$.

The amount of water in the enzyme was expressed as relative fraction of water (relation between the molar concentration of water in the enzyme and the molar concentration of the pure water) and this value was fixed in 0.5 (Table 1).

\section{Stability assays}

Enzyme solution of araujiain (lyophilized powder) containing $1 \mathrm{mg}$ (total content of proteins) / $\mathrm{ml}$ was prepared for stability assays in organic solvents with low water content. Each trial was performed by incubation of the mixture for $4 \mathrm{~h}$ at $40^{\circ} \mathrm{C}$, under controlled magnetic stirring. $0.1 \mathrm{ml}$ of the mixture was sampled at periodical intervals of time and residual caseinolytic activity was quantified.
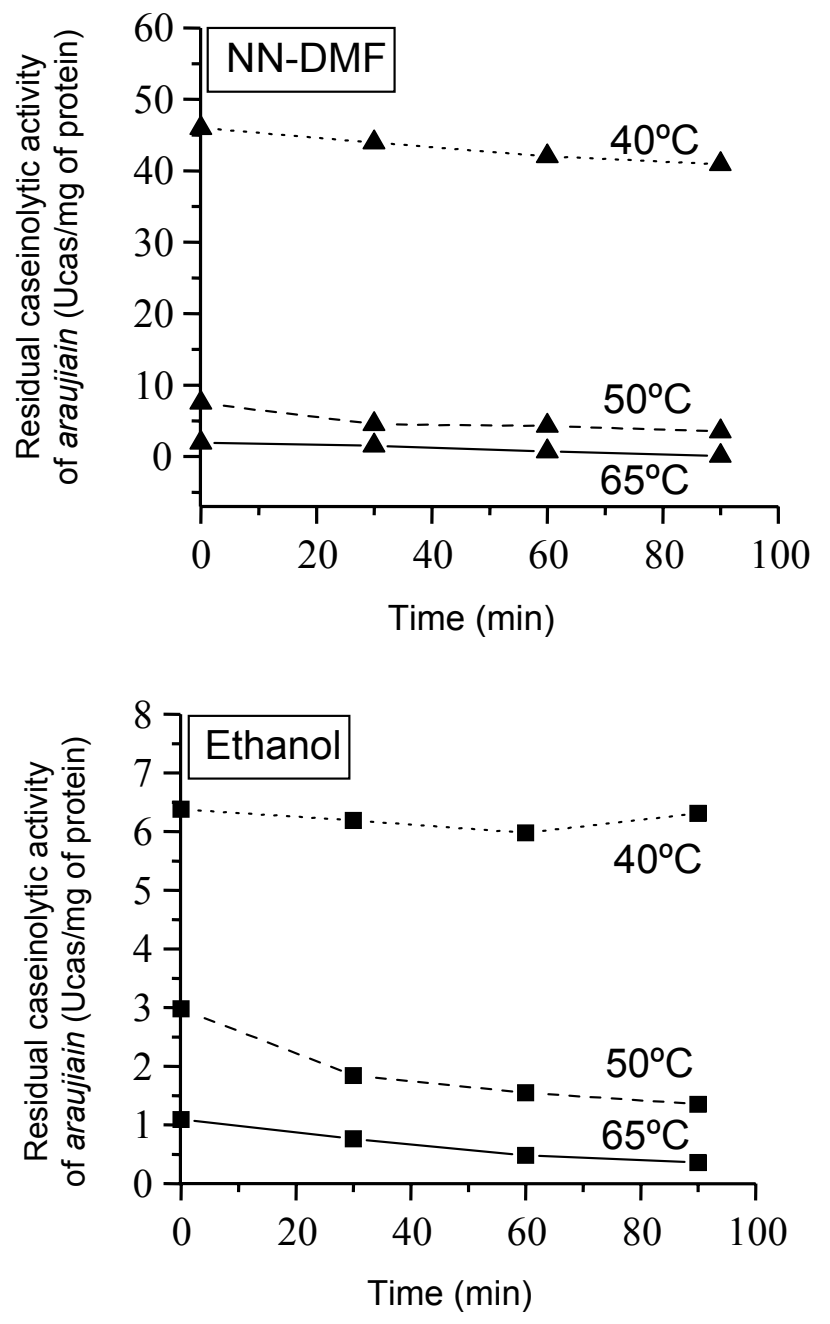

Figure 2. Residual caseinolytic activity of araujiain (Ucas/mg of protein) in $\mathrm{N}, \mathrm{N}$-dimethylformamide and ethanol (with low water content) as a function of temperature $\left(40,50\right.$ and $\left.65^{\circ} \mathrm{C}\right)$.

\section{Thermostability assays}

The thermal behavior of araujiain was evaluated by measuring the residual caseinolytic activity after incubation of the sample in Tris- $\mathrm{HCl}$ buffer $(\mathrm{pH} \mathrm{8})$, and in ethanol and $\mathrm{N}, \mathrm{N}$-dimethylformamide (with low water content) at 40, 50 
and $65^{\circ} \mathrm{C}$ at periodical intervals of time.

\section{Substrate preferences assays}

The substrate preferences were determined as esterolytic activity of araujiain according to Silverstein method (Priolo et al. 2000) using $N$ - $\alpha$-carbobenzoxy- $p$-nitrophenyl esters of some amino acids (Gln, Gly, Leu, Tyr, Phe and Pro). The synthetic substrates were obtained from Sigma Chem. Co. (St. Louis, USA). Assays were made at $40^{\circ} \mathrm{C}$ in $0.1 \mathrm{M}$ Tris-HCl buffer ( $\mathrm{pH} 8)$, and in N,Ndimethylformamide and ethylene glycol (with low water content), containing $20 \mathrm{mM}$ cysteine in the reaction mixture. Absorbance was measured at $405 \mathrm{~nm}$ every $10 \mathrm{sec}$ for $120 \mathrm{sec}$. In addition, blanks without enzymes and under the same reaction conditions were carried out. An arbitrary enzyme activity unit $\left(U_{c b z}\right)$ was defined as the amount of protease that released $1.0 \mathrm{mM}$ of p-nitrophenolate per min in the assay conditions. To determine the micromoles of $\mathrm{p}$ nitrophenolate produced during the reaction, a standard curve (p-nitrophenol 15-70 mM) was constructed.

\section{FTIR spectroscopy}

The infrared spectra were measured at $20^{\circ} \mathrm{C}$ with a Nicolet Protégé model 460 Fourier transform infrared spectrophotometer, provided with CsI beam splitter between 4000 and $225 \mathrm{~cm}^{-1}$. The spectral resolution was better than $2 \mathrm{~cm}^{-1}$ between 4000 and $2000 \mathrm{~cm}^{-1}$, and better than $1 \mathrm{~cm}^{-1}$ in the remaining ranks. Araujiain was incubated for $4 \mathrm{hrs}$ in Tris- $\mathrm{HCl}$ buffer $(\mathrm{pH} 8)$, and in ethylene glycol and N,N-dimethylformamide (with low water content). Afterwards, the samples were centrifuged in a low-speed centrifuge, and the obtained pellet was separated from the supernatant. Approximately $0.5-1.0 \mathrm{mg}$ of protein was combined with $600 \mathrm{mg}$ of potassium bromide and ground into a fine powder. The powder was annealed into a disc using a hydraulic press. This process has previously been shown not to alter the IR spectra of proteins (Prestrelski et al. 1993; Kendrick et al. 1996; Van der Weert et al. 2001). Referents spectra were recorded under identical scan conditions with only the corresponding medium (without enzyme).The spectra for water vapour were subtracted from the observed enzyme spectra according to previously established criteria with a double subtraction procedure (Dong et al. 1995). The correction of the basis line and the second-derivative infrared spectrum were carried out using OMNIC spectrophotometer program. The relative amounts of the different components from the band amide I were determined by means of the second-derivative analysis.

\section{RESULTS AND DISCUSSION}

\section{Effects of organic media with low water content on enzyme stability}

Since araujiain demonstrated a high stability in buffer at $40^{\circ} \mathrm{C}$ (Priolo et al. 2000), stability assays in different organic solvents with low and constant water content (relative fraction of water: 0.5 ) were carried out under the same reaction conditions.

According to Figure 1, caseinolytic activity profiles of araujiain showed the highest retention (Ucas/mg of protein) in N,N-dimethylformamide and ethanol, but these values were $76 \%$ higher in the former than in the latter, after 4 hrs. Moreover, araujiain in 1-octanol and toluene showed high initial caseinolytic activity, but an important autolysis degree and/or inactivation was observed by the effect of these organic solvents. Araujiain did not show any significant caseinolytic activity in the rest of the organic solvents.

It is important to point out that caseinolytic activity retention of araujiain in $0.1 \mathrm{M}$ Tris- $\mathrm{HCl}$ buffer $(\mathrm{pH} 8)$ was $2.1 \mathrm{Ucas} / \mathrm{mg}$ of protein after $4 \mathrm{hrs}$ of incubation at $40^{\circ} \mathrm{C}$. This value was 19 times lower than those obtained in N,Ndimethylformamide (with low water content).

\section{Effects of organic media with low water content on enzyme thermostability}

Two types of thermal instability of enzymes should be distinguished. The first type is time-dependent, and it represents a gradual and irreversible loss of enzymatic activity on exposure to high temperatures. The second one is heat-induced, unfolding usually almost instantaneous and reversible of enzyme molecules. Water is a pivotal participant in each case, by promoting both the conformational mobility of protein molecules and major deleterious reactions such as hydrolysis of peptide bound

Table 2. Substrate preferences of araujiain (Ucbz/mg of protein).

\begin{tabular}{|c|c|c|c|c|c|c|}
\hline \multirow[b]{2}{*}{$\begin{array}{c}N \text {-CBZ-amino acid- } p \text { - } \\
\text { nitrophenvl esters }\end{array}$} & \multicolumn{2}{|c|}{ Buffer } & \multicolumn{2}{|c|}{ Ethylene glycol } & \multicolumn{2}{|c|}{ N,N-Dimethylformamide } \\
\hline & $\begin{array}{l}\text { Ucbz/mg of } \\
\text { protein }\end{array}$ & $\%$ preference & $\begin{array}{l}\text { Ucbz/mg of } \\
\text { protein }\end{array}$ & $\%$ preference & $\begin{array}{l}\text { Ucbz/mg of } \\
\text { protein }\end{array}$ & $\%$ preference \\
\hline GIn & 53.31 & 100 & 13.45 & 72.7 & 1409.7 & 92.5 \\
\hline Gly & 16.44 & 32.4 & 9.34 & 50.5 & 752.7 & 49.4 \\
\hline Leu & 14.80 & 29.4 & 10.28 & 55.6 & 1528.7 & 100 \\
\hline Tyr & 10.67 & 21.8 & 9.02 & 48.7 & 156.8 & 10.3 \\
\hline Phe & 7.52 & 16.02 & 18.51 & 100 & 625.7 & 41 \\
\hline Pro & 0 & 0 & 11.55 & 62.4 & 4.6 & 0.3 \\
\hline
\end{tabular}


(Ahern and Klibanov, 1988; Rupley and Careri, 1991; Klibanov 2001). Hence, enzyme is expected to be more thermostable in organic solvents than in water. Nevertheless, araujiain had low residual caseinolytic activity in N,N-dimethylformamide and ethanol at temperatures higher than $40^{\circ} \mathrm{C}$, showing the same behavior that in buffer Tris- $\mathrm{HCl}$ (pH 8) (Priolo et al. 2000), although both organic solvents allowed to diminish the autolysis degree (Figure 2). That diminution of the autolysis degree could be due to a conformational change of araujiain in the organic media mentioned before.

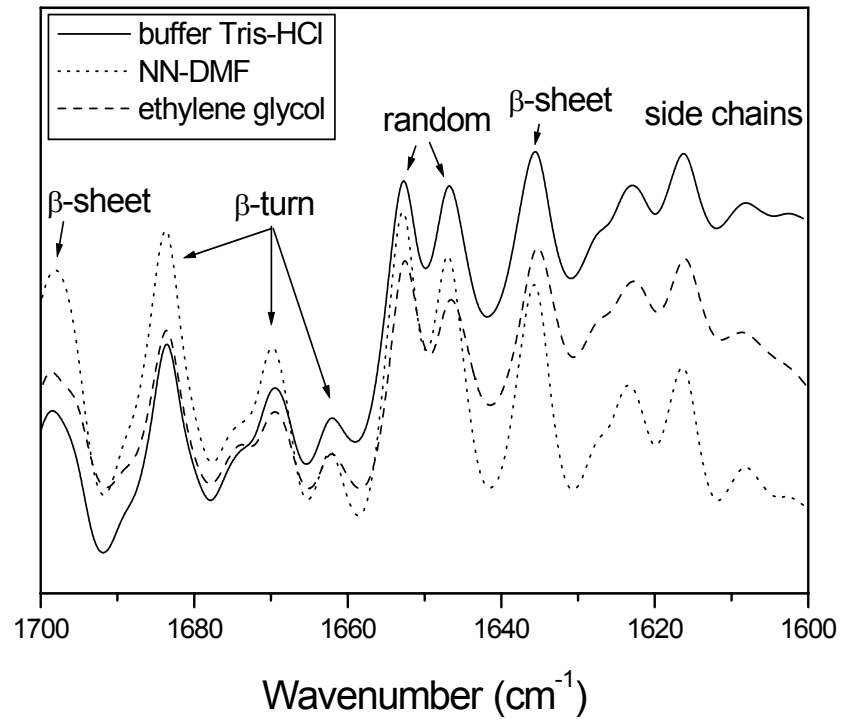

Figure 3. Infrared spectra of araujiain in $0.1 \mathrm{M}$ Tris- $\mathrm{HCl}$ buffer (pH 8), and in $\mathrm{N}, \mathrm{N}$-dimethylformamide and ethylene glycol (with low water content), at $25^{\circ} \mathrm{C}$.

\section{Effects of organic media with low water content on araujiain substrate specificity}

Table 2 shows the araujiain substrate preferences (esterolytic activity, $U c b z / \mathrm{mg}$ of protein) in $0.1 \mathrm{M}$ Tris- $\mathrm{HCl}$ buffer ( $\mathrm{pH} 8)$, and in ethylene glycol and N,Ndimethylformamide (with low water content). Ethylene glycol and N,N-dimethylformamide were selected because araujiain showed none and the highest residual caseinolytic activity after $4 \mathrm{~h}$, respectively.

According to these results, the highest esterolytic activities were found in $\mathrm{N}, \mathrm{N}$-dimethylformamide while the lowest esterolytic activities were found in ethylene glycol. Although the substrate preferences of araujiain exhibit different patterns, the enzyme showed a high preference for glutamine derivative in all media.

In buffer, hydrophobic and steric factors of the side chains of the amino acids reduced the esterase activity of the araujiain while the electronic interactions were very important in the increase of the esterolytic activity of the enzyme (Priolo et al. 2001). When water was substituted by an organic solvent, these effects did not permit to derive generalizations on the araujiain preferences. Nevertheless, the low affinity of araujiain for the Pro, Phe and Tyr derivatives in $\mathrm{N}, \mathrm{N}$-dimethylformamide might be influenced by the esteric effect of the side chains of these amino acids, which reduced the esterase activity of the enzyme.

We hypothesized that the changes in araujiain stability and preferences could be related to the conformational changes of the enzyme in each medium. A study of the secondary structure of araujiain in buffer, N,N-dimethylformamide and ethylene glycol was therefore carried out using FTIR spectroscopy.

Figure 3 shows the overlay of infrared spectra of araujiain in $0.1 \mathrm{M}$ Tris-HCl buffer $(\mathrm{pH}$ 8), and in N,Ndimethylformamide and ethylene glycol (with low water content), at $25^{\circ} \mathrm{C}$.

The amide I band (1700-1600 $\left.\mathrm{cm}^{-1}\right)$ arises primarily from the in plane $\mathrm{C}=\mathrm{O}$ stretching vibration of the peptide linkage that constitutes the backbone structure and is known to be sensitive to protein secondary structure and conformational changes, weakly coupled with $\mathrm{C}-\mathrm{N}$ stretching and in plane $\mathrm{N}-\mathrm{H}$ bending.

The frequency assignments for amide I components of araujiain in Tris- $\mathrm{HCl}$ buffer $(\mathrm{pH} 8)$, ethylene glycol and $\mathrm{N}, \mathrm{N}$-dimethylformamide (with low water content) were performed according to the literature (Table 3) (Kendrick et al. 1997; Barth, 2000; Dong et al. 2000).

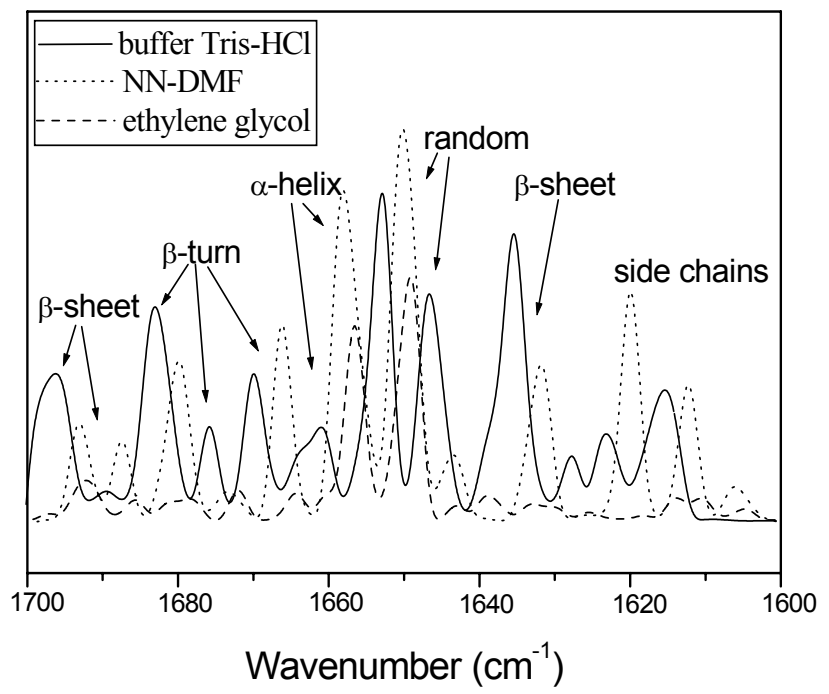

Figure 4. Curve fitted inverted second-derivative infrared spectra of araujiain in buffer Tris- $\mathrm{HCl}(\mathrm{pH} 8)$, and in $\mathrm{N}, \mathrm{N}-$ dimethylformamide and ethylene glycol (with low water content), at $25^{\circ} \mathrm{C}$.

Although the informational content of the primary spectrum is rather low, the conformational difference of araujiain among the studied media is detectable. In order to obtain more detailed structural information and to resolve the overlapping band components under the amide I contour, a second-derivative analysis of the original spectrum was 
carried out.

Figure 4 shows the curve fitted inverted second-derivative infrared spectra of araujiain in buffer Tris- $\mathrm{HCl}(\mathrm{pH} 8)$, in ethylene glycol and N,N-dimethylformamide (with low water content), at $25^{\circ} \mathrm{C}$. As observed in this figure, the maximum of amide I band of araujiain in those media was observed at $1653 \pm 2 \mathrm{~cm}^{-1}$ (random structure). Moreover, araujiain exhibits a lower $\alpha$-helical character and greater $\beta$ sheet folding in buffer than in ethylene glycol or N,Ndimethylformamide. Furthermore, this fact was demonstrated when comparing the $\beta$-sheet $/ \alpha$-helix relation areas, which were $0.63,0.47$ and 8.9 for N,Ndimethylformamide, ethylene glycol and buffer, respectively (Table 3).

On the other hand, the diminution and the disappearance of the $\beta$-sheet band to $1689 \mathrm{~cm}^{-1}$ along with the apparition or increase of a $\beta$-sheet band at greater wavenumber (1698 $\mathrm{cm}^{-1}$ ), which corresponds to intermolecular bonds, indicate the formation of enzymatic aggregates (Dong et al. 1995). This phenomenon was observed when araujiain was dissolved in buffer Tris- $\mathrm{HCl}(\mathrm{pH} 8)$.

A secondary structure with high $\alpha$-helical character is likely to be the cause of the high hydrolytic and esterolytic activities of araujiain in N,N-dimethlyformamide, in relation to the buffer. On the contrary, no correlation was observed between the activities of araujiain in ethylene glycol and the secondary structure.

Strictly, the correlation between enzyme structure and catalytic activity requires direct measurement of active-site structure and the effect of the reaction medium on the transition state of the reaction. Nevertheless, according to FTIR spectra it is clear that the noncovalent forces (hydrogen bonding, and ionic, hydrophobic and Van der Waals interactions) that maintain the native secondary and tertiary structures of enzymes were modified when araujiain was suspended in some organic media with low and constant water content.

These facts allow to verify that araujiain suspended in an organic solvent such as N,N-dimethylformamide (with low water content) changed its secondary structure and its substrate preferences and adopted a native-like conformation but with higher stability, very good hydrolytic potential and higher esterolytic activity than in an aqueous medium.

\section{ACKNOWLEDGMENTS}

Measurements of the infrared spectra were carried out by Dr. Gerardo Camí in the Laboratorio de Química Inorgánica, Universidad Nacional de San Luis. J. Marchese and S. Barberis are members of the CONICET Professional Career Programmes. E. Quiroga is CONICET fellow.

\section{REFERENCES}

ABBOUD, José-Luis M. and NOTARIO, Rafael. Critical compilation of scales of solvent parameters. Part I. Pure, non-hydrogen bond donor solvents. Pure and Applied Chemistry, 1999, vol. 71, no. 4, p. 645-718.

ABRAHAM, Michael H.; LIEB, William R. and FRANKS, Nicholas P. Role of hydrogen bonding in general anesthesia. Journal of Pharmaceutical Science, August 1991, vol. 80, no. 8, p. 719-724.

ABRAHAM, Michael H. and GRELLIER, P.L. Solvent effects in organic chemistry-recent developments. Canadian Journal of Chemistry, 1988, vol. 66, p. 26732686.

ABRAHAM, Michael H. and Mc GOWAN, J.C. The use of characteristic volumes to measure activity terms in reversed phase liquid chromatography. Chromatographia, April 1987, vol. 23, no. 4, p. 243-246.

AHERN, Tim J. and KLIBANOV Alexander M. Analysis of processes causing thermal inactivation of enzymes. Methods of Biochemical Analysis, 1988, vol. 33, p. 91-127.

BARTH, Andreas. The infrared absorption of amino acids side chains. Progress in Biophysics and Molecular Biology, 2000, vol. 74, no 3-5, p. 141-173.

CARREA, Giacomo and RIVA, Sergio. Properties and synthetic applications of enzymes in organic solvents.

Table 3. Frequency assignments and relative areas of the amide I components of araujiain in buffer Tris- $\mathrm{HCl}(\mathrm{pH} 8)$, and in ethylene glycol and N,N-dimethylformamide (with low water content).

\begin{tabular}{|l|c|c|c|c|}
\hline & & Buffer & Ethylene glycol & N,N-Dimethylformamide \\
\hline \multirow{3}{*}{$\beta$-sheet } & $v\left( \pm 2 \mathrm{~cm}^{-1}\right)$ & Relative areas & Relative areas & Relative areas \\
\cline { 2 - 5 } & 1636 & 4.88 & 1.609 & 2.31 \\
\cline { 2 - 5 } & 1689 & 0.56 & 1.742 & 3.955 \\
\hline a-helix & 1698 & 2.9 & 0.348 & 0.483 \\
\hline random & 1660 & 0.931 & 7.826 & 10.61 \\
\cline { 2 - 5 } & 1647 & 2.117 & 0.807 & 1.718 \\
\hline \multirow{3}{*}{-turn } & 1653 & 3.124 & 5.632 & 2.86 \\
\cline { 2 - 5 } & 1669 & 1.316 & 0.76 & 0.75 \\
\cline { 2 - 5 } & 1674 & 1.232 & 0.69 & 1.068 \\
\hline
\end{tabular}


Angewandte Chemie International Edition, July 2000, vol. 39 , no. 13 , p. 2226-2254.

CARREA, Giacomo; OTTOLINA, Gianluca and RIVA, Sergio. Role of solvents in the control of enzyme selectivity in organic media. Trends in Biotechnology, February 1995, vol. 13 , no. 2 , p. $63-70$.

COLOMBO, Giorgio; OTTOLINA, Gianluca and CARREA, Giacomo. Modelling of enzyme properties in organic solvents. Monatshefte für Chemie, 2000, vol. 131, no. 6 , p. $527-547$.

DONG, Aichun; MEYER, Jeffrey D.; BROWN, Jerry L.; MANNING, Mark C. and CARPENTER, John F. Comparative fourier transform infrared and circular dichroism spectroscopic analysis of $\alpha_{1}$-proteinase inhibitor and ovalbumin in aqueous solution. Archives of Biochemistry and Biophysics, November 2000, vol. 383, no. 1 , p. 148-155.

DONG, Aichun; PRESTRELSKI, Steven J.; ALLISON, Dean S. and CARPENTER, John F. Infrared spectroscopic studies of lyophilization- and temperature-induced protein aggregation. Journal of Pharmaceutical Science, 1995, vol. 84 , no. 4 , p. $415-424$.

HALLING, Peter J. Organic liquids and biocatalyst: theory and practice. TIBTECH, March 1989, vol. 7, p. 50-52.

ILLANES, Andrés and BARBERIS, Sonia. Catálisis enzimática en fase orgánica. In: Ediciones Universitarias de Valparaíso de la Universidad Católica de Valparaíso ed. Biotecnología de enzimas. Valparaíso, Chile, 1994, p. 227254.

KAWASHIRO, Katsuhiro; SUGAHARA, Hideki; SUGIYAMA, Shigeru and HAYASHI, Hiromu. Effect of organic solvents on enantioselectivity of protease catalysis. Biotechnology and Bioengineering, January 1997, vol. 53, no. 1, p. 26-31.

KE, Tao and KLIBANOV, Alexander M. On enzymatic activity in organic solvents as a function of enzyme history. Biotechnology and Bioengineering, March 1998, vol. 57, no. $6, \mathrm{p}$ 746-750.

KENDRICK, Brent S.; MEYER, Jeffrey D.; MATSUURA, James E.; CARPENTER, John F. and MANNING, Mark C. Hydrophobic ion pairing as a method of enhancing structure and activity of lyophilized subtilisin BPN' suspended in isooctane. Archives of Biochemistry and Biophysics, November 1997, vol. 347, no. 1, p. 113-118.

KENDRICK, Brent S.; DONG Aichun; ALLISON Dean S.; MANNING, Mark C. and CARPENTER, John F. Quantitation of the area of overlap between secondderivative amide I infrared spectra to determine the structural similarity of a protein in different states. Journal of Pharmaceutical Science, February 1996, vol. 85, no. 2, p. $155-158$.

KLIBANOV, Alexander M. Improving enzymes by using them in organic solvents. Nature, January 2001, vol. 409, p. 241-246.

LAITINEN, H.A. and HARRIS, W.E. Análisis Químico, Ed. Reverté: Barcelona. 1982. 652 p. ISBN 8429173242.

LORTIE, Robert. Enzyme catalyzed esterification. Biotechnology Advances, 1997, vol. 15, no. 1, p. 1-15.

OBREGON, Walter D.; ARRIBÉRE, Ma. Cecilia; MORCELLE del VALLE, Susana; LIGGIERI, Constanza; CAFFINI, Néstor and PRIOLO, Nora. Two new cysteine endopeptidases obtained from the latex of Araujia hortorum fruits. Journal of Protein Chemistry, May 2001, vol. 20, no. 4, p. 317-325.

PRESTRELSKI, Steven J.; TEDESCHI, Nicole; ARAKAWA, T. and CARPENTER, John F. Dehydrationinduced conformational transitions in proteins and their inhibition by stabilizers. Biophysical Journal, August 1993, vol. 65 , no. 2 , p. 661-671.

PRIOLO, Nora; ARRIBÉRE, Cecilia M.; CAFFINI, Néstor; BARBERIS, Sonia; NIETO VÁZQUEZ, Rodolfo and LUCO, Juan M. Isolated and purification of cysteine peptidase from the latex of Araujia hortorum fruits. Study of their esterase activities using partial least-squares (PLS) modeling. Journal of Molecular Catalysis B: Enzymatic, March 2001, vol. 635, no. 4-6, p. 1-13.

PRIOLO, Nora; MORCELlE del VALLE, Susana; ARRIBÉRE, M. Cecilia; LÓPEZ, Laura and CAFFINI, Néstor. Isolated and characterization of a cysteine protease from the latex of Araujia hortorum fruits. Journal of Protein Chemistry, January 2000, vol. 19, no. 1, p. 39-49.

REICHARDT, Christian. Solvatochromic dyes as solvent polarity indicators. Chemical Reviews, 1994, vol. 94, no. 8, p. 2319-2358.

RUPLEY, John A. and CARERI, Giorgio. Protein hydration and function. Advance in Protein Chemistry, 1991, vol. 41, p. 37-172.

VAN der WEERT, Marco; HARIS, Parvez I.; HENNINK, Wim E. and CROMMELIN, Daan J.A. Fourier transform infrared spectrometric analysis of protein conformation: effect of sampling methods and stress factors. Analytical Biochemistry, October 2001, vol. 297, no. 2, p. 160-169.

WESCOTT, Charles R. and KLIBANOV, Alexander M. The solvent dependence of enzyme specificity. Biochimica et Biophysica Acta (BBA)-General Subjects, May 1994, vol. 1206, no. 1, p. 1-9.

YENNAWAR, Hemant P.; YENNAWAR, Neela H. and FARBER, Gregory K. A structural explanation for enzyme 
Quiroga, E. et al.

memory in nonaqueous solvents. Journal of the American Chemical Society, January 1995, vol. 117, no. 2, p. 577585.

XU, Kui and KLIBANOV, Alexander M. pH control of the catalytic activity of cross-linked enzyme crystals in organic solvents. Journal of the American Chemical Society, October 1996, vol. 118, no. 41, p. 9815-9819.

ZAKS, Aleksey and KLIBANOV, Alexander M. The effect of water on enzyme action in organic media. Journal of Biological Chemistry, June 1988, vol. 263, no. 17, p. 80178021 . 